\title{
PENERAPAN MODEL PEMBELAJARAN PROJECT BASED LEARNING TERHADAP PENINGKATAN KEMAMPUAN BERPIKIR KRITIS DAN DISPOSISI MATEMATIS SISWA
}

Ikhbar Hafidzino Paranduri

SD IT Permata Indah

\begin{tabular}{l} 
INFO ARTICLES \\
\hline Article History: \\
Received: 20 Maret 2018 \\
Revised: 2 April 2018 \\
Approved: 9 April 2018 \\
Publish Online: 16 April 2018 \\
\hline
\end{tabular}

Key Words:

Project Based Learning, Critical Thinking, Disposition

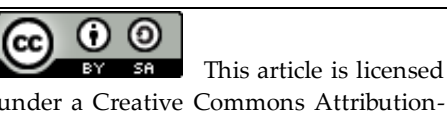

Shatribution

ShareAlike 4.0 International License.

\begin{abstract}
The purpose of this study was to determine the final achievement, improvement of critical thinking skills, and mathematical dispositions through project based learninglearning models. The population in this study were eighth grade students in one of the State Junior High Schools in Serang City 2014/2015 academic year. The sample was chosen by cluster random sampling technique from 8 classes, obtained one experimental class and one control class. The research method used is quasi-experimental method with non-equivalent research design. The number of samples in the experimental class and control class amounted to 30 students. The results showed: Mathematical critical thinking ability of students who obtained a project based learning in the high category. Enhancement students' critical thinking skills who obtain project based learning that are in the medium category. Mathematical disposition of students who obtain a project based learning model that belongs to the medium category. Enhancement mathematical disposition of students who obtain project based learning in the low category.
\end{abstract}

\begin{abstract}
Abstrak: Tujuan Penelitian ini adalah untuk mengetahui pencapaian akhir, peningkatan kemampuan berpikir kritis, dan disposisi matematis melalui model pembelajaran project based learning. Populasi pada penelitian ini adalah siswa kelas VIII di salah satu SMP Negeri di Kota Serang tahun ajaran 2014/2015. Sampel dipilih dengan teknik cluster random sampling dari 8 kelas, didapat satu kelas eksperimen dan satu kelas kontrol. Adapun metode penelitian yang digunakan adalah metode kuasi eksperimen dengan desain penelitian nonekivalen. Jumlah sampel kelas eksperimen dan kelas kontrol masing-masing berjumlah 30 siswa. Hasil penelitian menunjukkan : Kemampuan berpikir kritis matematis siswa yang memperoleh model pembelajaran project based learning yang termasuk ke dalam kategori tinggi. Peningkatan kemampuan berpikir kritis matematis siswa yang memperoleh pembelajaran project based learning yang termasuk ke dalam kategori sedang. Disposisi matematis siswa yang memperoleh model pembelajaran project based learning yang termasuk ke dalam kategori sedang. Peningkatan disposisi matematis siswa yang memperoleh pembelajaran project based learning yang termasuk ke dalam kategori rendah.
\end{abstract}

\footnotetext{
Correspondence Address: Jl. Raya Wijaya Kusuma No. 1, Komplek Dasana Indah, Kelapa Dua, Bojong Nangka, Tangerang, Banten 15820; e-mail: Hafidzino93@gmail.com

How to Cite (APA $6^{\text {th }}$ Style): Paranduri. (2018). Penerapan Model Pembelajaran Project Based Learning Terhadap Peningkatan Kemampuan Berpikir Kritis Dan Disposisi Matematis Siswa SMP. JKPM (Jurnal Kajian Pendidikan Matematika), Vol. 03 (02), 145-156.
}

Copyright: Paranduri, I.H, (2018)

Competing Interests Disclosures: The authors declare that they have no significant competing financial, professional or personal interests that might have influenced the performance or presentation of the work described in this manuscript. 


\section{PENDAHULUAN}

Kemajuan ilmu pengetahuan dan teknologi menyebabkan arus informasi menjadi cepat dan tanpa batas. Hal ini berdampak langsung pada berbagai bidang kehidupan, termasuk dalam bidang pendidikan. Lembaga pendidikan sebagai bagian dari sistem kehidupan telah berupaya mengembangkan struktur kurikulum, sistem pendidikan, dan model pembelajaran yang efektif dan efisien untuk meningkatkan sumber daya manusia yang berkualitas. Pendidikan merupakan kunci untuk semua kemajuan dan perkembangan yang berkualitas karena pendidikan merupakan proses perubahan tingkah laku siswa menjadi manusia dewasa yang mampu hidup mandiri dan sebagai anggota masyarakat dalam lingkungan alam sekitar. Peningkatan kualitas pendidikan harus dilakukan secara kontinu dan berkesinambungan. Faktor yang dapat menentukan kualitas pendidikan antara lain kualitas pembelajaran dan karakter siswa yang meliputi bakat, minat, dan kemampuan. Kualitas pembelajaran dapat dilihat dari interaksi siswa dengan sumber belajar dan pendidik. Interaksi yang berkualitas adalah yang menyenangkan dan dapat menciptakan pengalaman belajar. Shukor (Pritasari, 2011: 1) menyatakan bahwa untuk menghadapi perubahan dunia yang begitu pesat adalah dengan membentuk budaya berpikir kritis di masyarakat. Prioritas utama dari sebuah sistem pendidikan adalah mendidik siswa tentang bagaimana cara belajar dan berpikir kritis.

Pritasari (2011: 2) mengungkapkan bahwa berpikir kritis adalah keharusan dalam usaha menyelesaikan masalah, membuat keputusan, menganalisis asumsi-asumsi. Berpikir kritis diterapkan kepada siswa untuk belajar memecahkan masalah secara sistematis, inovatif, dan mendesain solusi yang mendasar. Siswa dapat menganalisis apa yang mereka pikirkan, menyintesis informasi, dan menyimpulkan melalui berpikir kritis. Berpikir kritis dapat dikembangkan melalui pembelajaran matematika karena matematika memiliki struktur dan kajian yang lengkap serta jelas antar konsep. Aktivitas berpikir kritis siswa dapat dilihat dari kemampuan siswa dalam menyelesaikan soal dengan lengkap dan sistematis. Matematika merupakan salah satu ilmu yang memilki peranan untuk meningkatkan kemampuan berpikir

kritis dan kreatif. Siswa memerlukan kemampuan berpikir kritis yang tinggi karena kemampuan berpikir kritis matematika berperan penting dalam penyelesaian suatu permasalahan mengenai pelajaran matematika. Selain itu, seorang siswa SMP telah dianggap dewasa sehingga diharapkan mampu berpikir kritis untuk mencapai hasil atau mengambil keputusan yang tepat dan bijaksana.

Belajar matematika akan berhasil jika proses belajar mengajar berjalan dengan baik, yaitu melibatkan intelektual siswa secara optimal. Menurut Djamarah dan Zain (2002: 177) bahwa kegiatan belajar mengajar tidak terlepas dari model pembelajaran. Pemilihan model, metode pembelajaran sangat menentukan keberhasilan siswa. Metode yang digunakan tidak sembarangan, melainkan sesuai dengan tujuan pembelajaran. Oleh karena itu, guru sebagai penyampai ilmu pengetahuan haruslah mampu mengajarkan matematika supaya lebih menarik, tidak membosankan, mudah dipahami dan mampu mengembangkan daya nalar serta kecerdasan yang dimiliki oleh siswa. Karena dalam kegiatan pembelajaran, proses pembelajaran biasanya diawali dengan menjelaskan konsep secara informatif, memberikan contoh soal dan diakhiri dengan pemberian latihan soal-soal. Akibat dari pembelajaran tersebut siswa yang belajar matematika lebih diarahkan pada proses menghafal dari pada memahami konsep. Menurut Mukhayat (Somakim, 2011: 43) belajar dengan menghafal tidak terlalu banyak menuntut aktivitas berpikir anak dan mengandung akibat buruk pada perkembangan mental anak. Anak akan cenderung suka mencari gampangnya saja dalam belajar. Anak kehilangan sense of learning, kebiasaan yang membuat anak bersikap pasif atau menerima begitu saja apa adanya mengakibatkan anak tidak terbiasa untuk berpikir kritis. Menurut Armanto (Somakim, 2011: 43), proses pembelajaran seperti inilah yang merupakan ciri pendidikan di negara berkembang termasuk di Indonesia. Selain itu, terdapat hubungan yang kuat antara disposisi matematis dan pembelajaran. 
Polking (dalam Syaban, 2008: 32) menyatakan bahwa disposisi matematis meliputi: (1) kepercayaan dalam menggunakan matematika untuk memecahkan permasalahan, untuk mengkomunikasikan gagasan, dan untuk memberikan alasan; (2) fleksibilitas dalam menyelidiki gagasan matematis dan berusaha mencari metode alternatif dalam memecahkan permasalahan; (3) tekun untuk mengerjakan tugasmatematika; (4) mempunyai minat, keingintahuan (cu riosity), dan daya temu dalam melakukan pekerjaan matematika; (5) kecenderungan untuk memonitor dan merefleksikan performance dan penalaran mereka sendiri; (6) menilai aplikasi matematika ke situasi lain yang timbul dalam matematika dan pengalaman sehari-hari; (7) penghargaan (appreciation) peran matematika dalam kultur dan nilai, baik matematika sebagai alat, maupun matematika sebagai bahasa. Dari beberapa indikator tersebut jelas bahwa disposisi matematis merupakan salah satu faktor yang ikut menentukan keberhasilan belajar siswa. Adanya keterkaitan antara kemampuan berpikir kritis dengan disposisi matematis yakni kurangnya kemampuan berpikir kritis matematis siswa akan berakibat pula pada rendahnya disposisi.

Pembelajaran matematika selain untuk meningkatkan kemampuan berpikir matematis atau aspek kognitif siswa, haruslah pula memperhatikan aspek afektif siswa, yaitu disposisi matematis. Pembelajaran matematika di kelas harus dirancang khusus sehingga selain dapat meningkatkan prestasi belajar siswa juga dapat meningkatkan disposisi matematis. Selanjutnya, NCTM (National Council of Teachers of Mathematics) menyatakan bahwa sikap siswa dalam menghadapi matematika dan keyakinannya dapat mempengaruhi prestasi mereka dalam matematika. Untuk menumbuh kembangkan kemampuan berpikir kritis matematis siswa diperlukan suatu model pembelajaran matematika yang mampu menumbuhkan kemampuan berpikir kritis matematis siswa. Salah satu model pembelajaran yang dapat digunakan untuk mengembangkan kemampuan berpikir kritis matematis adalah model pembelajaran project based learning.

Joel L Klein et. al (Widyantini, 2014: 3) menjelaskan bahwa pembelajaran project based learning adalah model pembelajaran yang memberdayakan siswa untuk memperoleh pengetahuan dan pemahaman baru berdasar pengalamannya melalui berbagai presentasi. Model pembelajaran Project based learning juga sangat sesuai dengan Permendikbud Nomor 81 A Tahun 2013 Lampiran IV mengenai proses pembelajaran yang harus memuat 5M, yaitu: (1) mengamati; (2) menanya; (3) mengumpulkan informasi; (4) mengasosiasi; dan (5) mengomunikasikan. Berdasarkan uraian di atas, maka peneliti mengadakan penelitian mengenai penerapan model pembelajaran Project Based Learning (PjBL) terhadap peningkatan kemampuan berpikir kritis dan disposisi matematis siswa SMP.

Tujuan dalam penelitian ini adalah untuk mengetahui pencapaian akhir kemampuan berpikir kritis matematis antara siswa yang mendapatkan pembelajaran menggunakan model pembelajaran project based learning lebih baik dari pada siswa yang mendapatkan pembelajaran scientific, untuk mengetahui peningkatan kemampuan berpikir kritis matematis siswa yang mendapatkan pembelajaran dengan menggunakan model project based learning lebih baik dari pada siswa yang mendapatkan pembelajaran scientific, untuk mengetahui pencapaian akhir disposisi matematis antara siswa yang mendapatkan pembelajaran menggunakan model project based learning lebih baik daripada siswa yang mendapatkan pembelajaran scientific, untuk mengetahui peningkatan disposisi matematis antara siswa yang mendapatkan 
pembelajaran menggunakan model project based learning lebih baik daripada siswa yang mendapatkan pembelajaran scientific.

\section{METODE}

Metode penelitian yang digunakan dalam penelitian ini adalah metode kuasi eksperimen. Penelitian kuasi eksperimen atau eksperimen semu adalah metode eksperimen yang tidak memungkinkan peneliti melakukan pengontrolan penuh terhadap variabel dan kondisi eksperimen. Pada penelitian ini, diberikan perlakuan terhadap variabel bebas kemudian diamati perubahan yang terjadi pada variabel terikat.Sebelum perlakuan diberikan pada penelitian ini dilakukan pretes, dan postes setelah perlakuan diberikan, sedangkan desain penelitian yang digunakan adalah desain kelompok kontrol non-ekuivalen (Non-Equivalent Control Group Design).

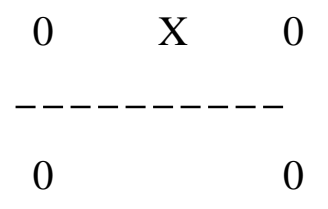

(Ruseffendi, 2005: 53)

Populasi dalam penelitian ini adalah seluruh siswa SMP kelas VIII. Siswa kelas VIII yang terdiri dari empat kelas dipilih menjadi 2 kelas secara acak, yaitu kelas VIII E menjadi kelas eksperimen dan kelas VIII H menjadi kelas kontrol. Penarikan sampel yang digunakan dalam penelitian ini adalah teknik cluster random sampling karena satuan yang dipilih bukanlah individu-individu, melainkan sekelompok individu yang secara alami berada bersama-sama di satu tempat, dengan catatan yang dirandom adalah kelasnya. (Ruseffendi, 2010 : 94)

Untuk menjawab permasalahan dan membuktikan hipotesis, dibuat instrumen penelitian sebagai alat bantu untuk mengumpulkan data. Instrumen ini digunakan untuk menghitung variabel yang diteliti dan digunakan untuk rumusan masalah yang telah dipaparkan sebelumnya. Berupa tes uraian yang diberikan sesuai dengan indikator kemampuan berpikir kritis matematis. Pedoman skor berpikir kritis matematika dapat dilihat pada tabel berikut.

Tabel 1. Rubrik Penskoran Berpikir Kritis Matematis

\begin{tabular}{|l|l|l|l|l|}
\hline \multirow{2}{*}{\multicolumn{1}{|c|}{ Indikator }} & \multicolumn{1}{|c|}{$\mathbf{4}$} & \multicolumn{1}{c|}{$\mathbf{3}$} & \multicolumn{1}{c|}{$\mathbf{2}$} & \multicolumn{1}{c|}{$\mathbf{1}$} \\
\cline { 2 - 5 } $\begin{array}{l}\text { Memecahkan } \\
\text { masalah } \\
\text { (Menentukan } \\
\text { informasi yang } \\
\text { diberikan) }\end{array}$ & $\begin{array}{l}\text { Menunjukkan } \\
\text { pemecahan yang } \\
\text { lebih terhadap } \\
\text { masalah } \\
\text { matematika. }\end{array}$ & $\begin{array}{l}\text { Menunjukkan } \\
\text { pemecahan } \\
\text { terhadap masalah } \\
\text { matematika. }\end{array}$ & $\begin{array}{l}\text { Menunjukkan } \\
\text { pemecahan } \\
\text { terhadap sebagian } \\
\text { masalah } \\
\text { matematika. }\end{array}$ & $\begin{array}{l}\text { Menunjukkan } \\
\text { sedikit atau tidak } \\
\text { ada pemecahan } \\
\text { terhadap sebagian } \\
\text { masalah } \\
\text { matematika. }\end{array}$ \\
\hline $\begin{array}{l}\text { Mengidentifikasi } \\
\text { dan menjastifikasi } \\
\text { konsep }\end{array}$ & $\begin{array}{l}\text { Mengidentifikasi } \\
\text { dan menjastifikasi } \\
\text { semua konsep } \\
\text { matematika } \\
\text { dengan tepat. }\end{array}$ & $\begin{array}{l}\text { Mengidentifikasi } \\
\text { dan menjastifikasi } \\
\text { sebagian konsep } \\
\text { matematika } \\
\text { dengan tepat. }\end{array}$ & $\begin{array}{l}\text { Mengidentifikasi } \\
\text { dan menjastifikasi } \\
\text { sebagian konsep } \\
\text { matematika }\end{array}$ & $\begin{array}{l}\text { Mengidentifikasi } \\
\text { dan menjastifikasi } \\
\text { sedikit konsep } \\
\text { matematika }\end{array}$ \\
\hline
\end{tabular}




\begin{tabular}{|l|l|l|l|l|}
\hline & & & $\begin{array}{l}\text { dengan kurang } \\
\text { tepat. }\end{array}$ & $\begin{array}{l}\text { dengan kurang } \\
\text { tepat. }\end{array}$ \\
\hline $\begin{array}{l}\text { Menganalisis } \\
\text { algoritma }\end{array}$ & $\begin{array}{l}\text { Menggeneralisasi } \\
\text { algoritma yang } \\
\text { sesuai dengan } \\
\text { benar. }\end{array}$ & $\begin{array}{l}\text { Pada umumnya } \\
\text { menggeneralisasi } \\
\text { algoritma yang } \\
\text { sesuai dengan } \\
\text { benar. }\end{array}$ & $\begin{array}{l}\text { Pada umumnya } \\
\text { menggeneralisasi } \\
\text { algoritma yang } \\
\text { sesuai dengan } \\
\text { sebagian benar. }\end{array}$ & $\begin{array}{l}\text { Tidak } \\
\text { menggeneralisasi } \\
\text { algoritma yang } \\
\text { sesuai dan tidak } \\
\text { benar. }\end{array}$ \\
\hline Menggeneralisasi & $\begin{array}{l}\text { Menggeneralisasi } \\
\text { semua } \\
\text { permasalahan } \\
\text { yang diinginkan } \\
\text { dengan serta } \\
\text { benar. }\end{array}$ & $\begin{array}{l}\text { Menggeneralisasi } \\
\text { semua } \\
\text { permasalahan } \\
\text { yang diinginkan } \\
\text { serta pada } \\
\text { umumnya benar. }\end{array}$ & $\begin{array}{l}\text { Menggeneralisasi } \\
\text { cukup memenuhi } \\
\text { sebagian } \\
\text { permasalahan } \\
\text { yang diinginkan } \\
\text { serta pada } \\
\text { umumnya benar. }\end{array}$ & $\begin{array}{l}\text { Mengeneralisasi } \\
\text { tidak memenuhi } \\
\text { perminytaan } \\
\text { permasalahan } \\
\text { yang diinginkan } \\
\text { serta tidak benar. }\end{array}$ \\
\hline
\end{tabular}

Ratnaningsih (Nurrochmatunnisa, 2013: 11)

Instrumen yang sudah dibuat dilakukan analisis mengenai validitas butir soal, reliabilitas, daya pembeda dan indeks kesukaran butir soal tersebut.

Instrumen non-tes yang digunakan berupa angket. Angket adalah jenis evaluasi yang berupa daftar pernyataan atau pertanyaan yang dijawab oleh responden (dalam hal ini siswa) berkenaan dengan sikap, tugas, sajian, aspirasi, fasilitas, suasana pembelajaran dan lain-lain. Data non-tes diperoleh dari angket sikap siswa terhadap pelajaran matematika dengan menggunakan model pembelajaran project based learning. Angket yang digunakan dalam penelitian ini adalah angket tertutup dengan kategori jawaban sangat setuju (SS), setuju (S), tidak setuju (TS), dan sangat tidak setuju (STS).Untuk penskoran digunakan skala Likert sebagai skala pengukurannya.skala kategori Likert, jawaban diberi bobot atau disamakan dengan nilai kuantitatif 4, 3, 2, 1, untuk empat pilihan pernyataan positif dan 1, 2, 3, 4 untuk empat pernyataan yang bersifat negatif. Berikut tabel penskoran skala disposisi :

Tabel 2. Rubrik Penskoran Skala Disposisi Matematis

\begin{tabular}{|c|c|c|}
\hline \multirow{2}{*}{ Alternatif Jawaban } & \multicolumn{2}{|c|}{ Jenis Pernyataan } \\
\cline { 2 - 3 } & Positif & Negatif \\
\hline Sangat Sering (SS) & 4 & 1 \\
\hline Sering (S) & 3 & 2 \\
\hline Tidak Sering (TS) & 2 & 3 \\
\hline Sangat Tidak Sering (STS) & 1 & 4 \\
\hline
\end{tabular}

Penyusunan instrumen skala disposisi matematis ini diawali dengan pembuatan kisi-kisi skala disposisi matematis sebagai berikut: 
Tabel 3.Kisi-kisi Skala Disposisi Matematis

\begin{tabular}{|l|c|c|}
\hline \multicolumn{1}{|c|}{ Indikator } & \multicolumn{2}{c|}{ Pernyataan } \\
\cline { 2 - 3 } & Positif & Negatif \\
\hline $\begin{array}{l}\text { Rasa percaya diri dalam menggunakan matematika, memecahkan } \\
\text { masalah, memberi alasan dan mengkomunikasikan gagasan. }\end{array}$ & 1 & $2,3,5$ \\
\hline $\begin{array}{l}\text { Fleksibilitas dalam menyelidiki gagasan matematik dan berusaha } \\
\text { mencari metode alternatif dalam memecahkan masalah. }\end{array}$ & 4,6 & 7,12 \\
\hline Tekun mengerjakan tugas matematika. & 8,10 & 11 \\
\hline $\begin{array}{l}\text { Minat, rasa ingin tahu dan daya temu dalam melakukan tugas } \\
\text { matematika. }\end{array}$ & 9 & - \\
\hline $\begin{array}{l}\text { Cenderung memonitor, merefleksikan performance, dan penalaran } \\
\text { mereka sendiri. }\end{array}$ & 13,14 & - \\
\hline $\begin{array}{l}\text { Menilai aplikasi matematika ke situasi lain dalam matematika dan } \\
\text { pengalaman sehari-hari. }\end{array}$ & 15 & 16 \\
\hline $\begin{array}{l}\text { Apresiasi peran matematika dalam kultur dan nilai matematika sebagai } \\
\text { alat dan sebagai bahasa. }\end{array}$ & $17,18,19$ & 20 \\
\hline
\end{tabular}

\section{HASIL}

Presentase postes kemampuan berpikir kritis matematis setiap indikator memaparkan mengenai presentase postes kemampuan berpikir kritis matematis siswa kelas eksperimen dan kelas kontrol. Berikut Pemaparan presentase postes kemampuan berpikir kritis matematis.

Tabel 4. Presentase Postes Kemampuan Berpikir Kritis Matematis

\begin{tabular}{|c|c|c|c|c|}
\hline \multirow{2}{*}{ Kelas } & \multicolumn{4}{|c|}{ Presentase } \\
\cline { 2 - 5 } & Indikator 1 & Indikator 2 & Indikator 3 & Indikator 4 \\
\hline Eksperimen & $92,50 \%$ & $71,75 \%$ & $62,50 \%$ & $95,75 \%$ \\
\hline Kontrol & $65,75 \%$ & $43,25 \%$ & $55,00 \%$ & $59,25 \%$ \\
\hline
\end{tabular}

Presentase disposisi matematis siswa memaparkan mengenai presentase skala akhir disposisi matematis siswa kelas eksperimen dan kelas kontrol. Pemaparan presentase skala akhir disposisi matematis siswa setiap indikator sebagai berikut:

1) Rasa Percaya Diri Dalam Menggunakan Matematika, Memecahkan Masalah, Memberi Alasan dan Mengkomunikasikan Gagasan.

Indikator ini siswa memiliki rasa percaya diri dalam menggunakan matematika, memecahkan masalah, memberi alasan dan mengkomunikasikan gagasan. Indikator ini diwakili oleh pernyataan nomor 1, 2, 3 dan 5, yaitu nomor 1 sebagai pernyataan positif dan nomor 2, 3 dan 5 sebagai pernyataan negatif. Presentase hasil skala akhir siswa pada indikator ini dijelaskan dalam tabel berikut: 
Tabel 5.Presentase Rasa Percaya Diri dalam Menggunakan Matematika

\begin{tabular}{|l|c|c|c|c|c|c|}
\hline \multicolumn{1}{|c|}{ Kelas } & No 1 & No 2 & No 3 & No 5 & Rata-rata & $\begin{array}{c}\text { Kriteria } \\
\text { presentase }\end{array}$ \\
\hline Eksperimen & $76,75 \%$ & $62,50 \%$ & $71,75 \%$ & $57,50 \%$ & $67,12 \%$ & Sedang \\
\hline Kontrol & $81,75 \%$ & $60,75 \%$ & $59,25 \%$ & $60,00 \%$ & $65,44 \%$ & Sedang \\
\hline
\end{tabular}

Berdasarkan Tabel 5 terlihat bahwa rata-rata presentase rasa percaya diri dalam menggunakan matematika, memecahkan masalah, memberi alasan dan mengomunikasikan gagasan kelas eksperimen lebih besar dibandingkan kelas kontrol.

2) Fleksibilitas dalam Menyelidiki Gagasan Matematika dan Berusaha Mencari Metode Alternatif dalam Memecahkan Masalah

Indikator ini diwakili oleh 4 item yaitu nomor 4, 6, 7 dan 12, dimana nomor 4 dan 6 merupakan pernyataan positif dan nomor 7 dan 12 merupakan pernyataan negatif. Presentase hasil skala akhir pada indikator ini dijelaskan pada tabel di bawah ini :

Tabel 6.Presentase Fleksibilitas dalam Menyelidiki Gagasan Matematika

\begin{tabular}{|l|c|c|c|c|c|c|}
\hline \multicolumn{1}{|c|}{ Kelas } & No 4 & No 6 & No 7 & No 12 & Rata-rata & $\begin{array}{c}\text { Kriteria } \\
\text { presentase }\end{array}$ \\
\hline Eksperimen & $82,50 \%$ & $76,75 \%$ & $79,25 \%$ & $63,25 \%$ & $75,44 \%$ & Sedang \\
\hline Kontrol & $78,25 \%$ & $68,25 \%$ & $69,25 \%$ & $55,75 \%$ & $67,88 \%$ & Sedang \\
\hline
\end{tabular}

Berdasarkan Tabel 6 terlihat bahwa rata-rata presentase fleksibilitas dalam menyelidiki gagasan matematika dan berusaha mencari metode alternatif dalam memecahkan masalah kelas eksperimen lebih besar dibandingkan kelas kontrol.

3) Tekun Mengerjakan Tugas Matematika

Indikator ini diwakili oleh 3 item yaitu nomor 8, 10 dan 11, dimana nomor 8 dan 10 merupakan pernyataan positif dan nomor 11 merupakan pernyataan negatif. Presentase hasil skala akhir pada indikator ini dijelaskan pada tabel di bawah ini: 
Tabel 7. Presentase Tekun Mengerjakan Tugas Matematika

\begin{tabular}{|l|c|c|c|c|c|}
\hline \multicolumn{1}{|c|}{ Kelas } & No 8 & No 10 & No 11 & Rata-rata & $\begin{array}{c}\text { Kriteria } \\
\text { presentase }\end{array}$ \\
\hline Eksperimen & $74,25 \%$ & $78,25 \%$ & $74,25 \%$ & $75,58 \%$ & Sedang \\
\hline Kontrol & $75,00 \%$ & $63,25 \%$ & $60,75 \%$ & $66,33 \%$ & Sedang \\
\hline
\end{tabular}

Berdasarkan Tabel 7 terlihat bahwa rata-rata presentase tekun mengerjakan tugas matematika kelas eksperimen lebih besar dibandingkan kelas kontrol.

4) Minat, Rasa Ingin Tahu dan Daya Temu dalam Melakukan Tugas Matematika

Indikator ini diwakili oleh 1 item yaitu nomor 9, dimana nomor 9 merupakan pernyataan positif. Presentase hasil skala akhir pada indikator ini dijelaskan pada tabel di bawah ini:

Tabel 8. Presentase Minat, Rasa Ingin Tahu dan Daya Temu dalam Melakukan Tugas Matematika

\begin{tabular}{|l|c|c|c|}
\hline \multicolumn{1}{|c|}{ Kelas } & No 9 & Rata-rata & $\begin{array}{c}\text { Kriteria } \\
\text { presentase }\end{array}$ \\
\hline Eksperimen & $67,50 \%$ & $67,50 \%$ & Sedang \\
\hline Kontrol & $65,00 \%$ & $65,00 \%$ & Sedang \\
\hline
\end{tabular}

Berdasarkan Tabel 8 terlihat bahwa rata-rata presentase minat, rasa ingin tahu dan daya temu dalam melakukan tugas matematika kelas eksperimen lebih besar dibandingkan kelas kontrol.

5) Cenderung Memonitor, Merefleksikan Performance, dan Penalaran Mereka Sendiri

Indikator ini diwakili oleh 2 item yaitu nomor 13 dan 14 , dimana nomor 13 dan 14 merupakan pernyataan positif. Presentase hasil skala akhir pada indikator ini dijelaskan pada tabel di bawah ini:

Tabel 9. Presentase Cenderung Memonitor, Merefleksikan Performance, dan Penalaran Mereka Sendiri

\begin{tabular}{|l|c|c|c|c|}
\hline \multicolumn{1}{|c|}{ Kelas } & No 13 & No 14 & Rata-rata & Kriteria presentase \\
\hline Eksperimen & $75,75 \%$ & $77,50 \%$ & $76,62 \%$ & Sedang \\
\hline Kontrol & $71,75 \%$ & $75,00 \%$ & $73,38 \%$ & Sedang \\
\hline
\end{tabular}

Berdasarkan Tabel 9 terlihat bahwa rata-rata presentase cenderung memonitor, merefleksikan performance, dan penalaran mereka sendiri kelas eksperimen lebih besar dibandingkan kelas kontrol.

6) Menilai Aplikasi Matematika Ke Situasi Lain Dalam Matematika dan Pengalaman Sehari-hari

Indikator ini diwakili oleh 2 item yaitu nomor 15 dan 16, dimana nomor 15 merupakan pernyataan positif dan nomor 16 merupakan pernyataan negatif. Presentase hasil skala akhir pada indikator ini dijelaskan pada tabel di bawah ini: 
Tabel 10. Persentase Menilai Aplikasi Matematika

\begin{tabular}{|l|c|c|c|c|}
\hline \multicolumn{1}{|c|}{ Kelas } & No 15 & No 16 & Rata-rata & Kriteria presentase \\
\hline Eksperimen & $75,75 \%$ & $70,00 \%$ & $72,88 \%$ & Sedang \\
\hline Kontrol & $70,75 \%$ & $62,50 \%$ & $66,62 \%$ & Sedang \\
\hline
\end{tabular}

Berdasarkan Tabel 10 terlihat bahwa rata-rata presentase menilai aplikasi matematika ke situasi lain dalam matematika dan pengalaman sehari-hari kelas eksperimen lebih besar dibandingkan kelas kontrol.

7) Apresiasi Peran Matematika dalam Kultur dan Nilai Matematika Sebagai Alat dan Sebagai Bahasa

Indikator ini diwakili oleh 4 item yaitu nomor 17, 18, 19 dan 20, dimana nomor 17, 18 dan 19 merupakan pernyataan positif dan nomor 20 merupakan pernyataan negatif. Presentase hasil skala akhir pada indikator ini dijelaskan pada tabel di bawah ini:

Tabel 11. Presentase Apresiasi Peran Matematika

\begin{tabular}{|l|c|c|c|c|c|c|}
\hline \multicolumn{1}{|c|}{ Kelas } & No 17 & No 18 & No 19 & No 20 & Rata-rata & $\begin{array}{c}\text { Kriteria } \\
\text { presentase }\end{array}$ \\
\hline Eksperimen & $76,75 \%$ & $81,75 \%$ & $69,25 \%$ & $67,50 \%$ & $73,81 \%$ & Sedang \\
\hline Kontrol & $66,75 \%$ & $77,50 \%$ & $69,25 \%$ & $60,75 \%$ & $68,56 \%$ & Sedang \\
\hline
\end{tabular}

Berdasarkan Tabel 11 terlihat bahwa rata-rata presentase apresiasi peran matematika dalam kultur dan nilai matematika sebagai alat dan sebagai bahasa kelas eksperimen lebih besar dibandingkan kelas kontrol.

\section{PEMBAHASAN}

Berdasarkan hasil penelitian, didapatkan bahwa: (1) pencapaian akhir kemampuan berpikir kritis matematis antara siswa yang mendapatkan model pembelajaran project based learning yang termasuk ke dalam kategori sangat tinggi lebih baik daripada siswa yang mendapatkan pembelajaran scientific yang termasuk ke dalam kategori sedang; (2) peningkatan kemampuan berpikir kritis matematis pada siswa yang mendapatkan model pembelajaran project based learning yang termasuk ke dalam kategori tinggi lebih baik daripada siswa yang mendapatkan pembelajaran scientific yang termasuk ke dalam kategori sedang; (3) Pencapaian akhir disposisi matematis matematis siswa yang mendapatkan model pembelajaran project based learning yang termasuk ke dalam kategori tinggi lebih baik daripada siswa yang mendapatkan pembelajaran scientific yang termasuk ke dalam kategori tinggi. Pencapaian akhir kemampuan disposisi matematis siswa termasuk ke dalam kategori tinggi namun pada kelas dengan model pembelajaran project based learning memiliki rata-rata yang lebih besar dari kelas dengan pembelajaran scientific; (4) 
Peningkatan disposisi matematis siswa yang mendapatkan model pembelajaran project based learning yang termasuk ke dalam kategori sedang lebih baik daripada yang mendapatkan pembelajaran scientific dengan kategori sedang. Keduanya termasuk ke dalam kategori sedang namun pada kelas dengan model pembelajaran project based learning memiliki rata-rata yang lebih besar dari kelas dengan pembelajaran scientific. Hasil penelitian ini sesuai dengan penelitian sebelumnya yang dilakukan oleh Husnidar, dkk (2014) , bahwa (1) rata-rata kemampuan berpikir kritis matematis siswa yang diajarkan dengan problem based learning lebih tinggi dari siswa yang diajarkan secara konvensional; (2) Rata-rata N-gain disposisi matematis siswa yang diajarkan dengan PBM lebih tinggi dari N-Gain disposisi matematis siswa yang diajarkan secara konvensional. Hal ini menunjukkan bahwa Secara keseluruhan, peningkatan kemampuan berpikir kritis matematis siswa yang diajarkan dengan model pembelajaran berbasis masalah pada materi bangun ruang lebih tinggi daripada siswa yang diajarkan secara konvensional pada materi yang sama dan Pada pengelompokan siswa menurut peringkat, peningkatan kemampuan berpikir kritis matematis siswa yang diajarkan dengan model pembelajaran berbasis masalah lebih tinggi dari siswa yang diajarkan secara konvensional terjadi pada kelompok tinggi dan kelompok sedang saja.

\section{SIMPULAN}

Berdasarkan hasil penelitian yang dilaksanakan di salah satu SMP Negeri di Kota Serang, penerapan model pembelajaran project based learning diperoleh simpulan sebagai berikut:

- Pencapaian akhir kemampuan berpikir kritis matematis antara siswa yang mendapatkan model pembelajaran project based learning yang termasuk ke dalam kategori sangat tinggi lebih baik daripada siswa yang mendapatkan pembelajaran scientific yang termasuk ke dalam kategori sedang.

- Peningkatan kemampuan berpikir kritis matematis pada siswa yang mendapatkan model pembelajaran project based learning yang termasuk ke dalam kategori tinggi lebih baik daripada siswa yang mendapatkan pembelajaran scientific yang termasuk ke dalam kategori sedang.

- Pencapaian akhir disposisi matematis matematis siswa yang mendapatkan model pembelajaran project based learning yang termasuk ke dalam kategori tinggi lebih baik daripada siswa yang mendapatkan pembelajaran scientific yang termasuk ke dalam kategori tinggi. Pencapaian akhir kemampuan disposisi matematis siswa termasuk ke dalam kategori tinggi namun pada kelas dengan model pembelajaran project based learning memiliki rata-rata yang lebih besar dari kelas dengan pembelajaran scientific.

- Peningkatan disposisi matematis siswa yang mendapatkan model pembelajaran project based learning yang termasuk ke dalam kategori sedang lebih baik daripada yang mendapatkan pembelajaran scientific dengan kategori sedang. Keduanya termasuk ke dalam kategori sedang namun pada kelas dengan model pembelajaran project based learning memiliki rata-rata yang lebih besar dari kelas dengan pembelajaran scientific.

Bagi guru dan peneliti yang akan menerapkan model pembelajaran project based learning selanjutnya, adapun saran dari peneliti di antaranya :

- Bagi guru yang akan menerapkan model pembelajaran project based learning, diperlukan pengelolaan kelas dan koordinasi yang baik. Karena jika koordinasi kurang baik, dapat mengakibatkan siswa hanya bermain-main atau mengandalkan temannya untuk menyelesaikan pekerjaannya. 
- Bagi guru yang akan menerapkan model pembelajaran project based learning, pada tahap monitoring guru diharuskan setiap pertemuannya menagih kemajuan pekerjaan dari proyek yang tengah dibuat, agar hasil dari proyek tersebut bisa dikumpulkan dan dipresentasikan tepat pada waktu yang telah ditentukan.

- Bagi guru yang akan menerapkan model pembelajaran project based learning dalam pembelajaran. Memerlukan kemampuan guru untuk membimbing siswa dalam kelas yang besar, apalagi kemampuan dan karakteristik siswanya sangat beragam.

- Bagi guru yang akan menerapkan model pembelajaran project based learning dalam pembelajaran, harus dapat memperhitungkan banyaknya soal serta waktu pengerjaan soal-soal sehingga memungkinkan untuk mengevaluasi atau mengkonfirmasi hasil jawaban siswa.

- Pembentukan kelompok harus dibagi secara adil dan merata, dalam satu kelompok harus terdapat siswa yang berkemampuan rendah dan juga terdapat siswa yang berkemampuan tinggi.

- Bagi peneliti selanjutnya, perlu mencoba apakah ada korelasi antara kemampuan berpikir kritis dan disposisi matematis siswa.

\section{DAFTAR PUSTAKA}

Djamarah \& Zain. (2002). Strategi Belajar Mengajar. Jakarta: Rineka Cipta.

Husnidar, dkk. (2014). Penerapan Model Pembelajaran Berbasis Masalah untuk Meningkatkan Kemampuan Berpikir Kritis dan Disposisi Matematis Siswa. Jurnal Didaktik Matematika.

Nurrochmatunnisa, D. (2013). Pengaruh Model Reciprocal Teaching terhadap Peningkatan Kemampuan Berpikir Kritis Matematis bagi Siswa Kelas IX MTS. Universitas Sultan Ageng Tirtayasa (UNTIRTA) Serang.[20 Desember 2014. Pukul 19.11 WIB]

Pritasari, A. D. M. (2011). Upaya Meningkatkan Kemampuan Berpikir Kritis Siswa Kelas XI IPA 2 Sekolah Menengah Atas Negeri 8 Yogyakarta pada Pembelajaran Matematika Melalui Pembelajaran Kooperatif Tipe Group Investigation (GI). [Online]. Tersedia: http://eprints.uny.ac.id/2384/1/skripsi \%28ajeng desi-07301241049\%29.pdf [Oktober 2014. 3.45 WIB]

Ruseffendi, E.T. (2005). Dasar-dasar Penelitian Pendidikan dan Bidang non Eksaktalainnya. Bandung: Tarsito.

Somakim, 2011. Peningkatan Kemampuan Berpikir Kritis Matematis Siswa Sekolah Menengah Pertama dengan Menggunakan Pendidikan Matematik Realistik. Universitas Sriwijaya Palembang [Online]. Tersedia:http://www.google.com/url?sa=t\&rct=j\&q=\&esrc=s\&source=web\&cd=1\&ved=0CCAQF jAA\&url=http\%3A\%2F\%2Feprints.unsri.ac.id\%2F1526\%2F1\%2F08-

Somakim_Matematika-\%25284248\%2529.pdf\&ei=E2aVVMbhBYzluQTmmoKICQ\&usg=AFQjC NHwUv7RtgmlFG7VKEcyYVgk6z0LDA\&bvm=bv.82001339,d.c2E 
156 Paranduri

Syaban, Mumun. (2008). Menumbuhkembangkan Daya dan Disposisi Matematis Siswa Sekolah Menengah Atas Melalui Pembelajaran Investigasi. Universitas Langlangbuana Bandung [Online]. Tersedia: http://jurnal.upi.edu/penelitian-pendidikan/author/mumun-syaban [21 Desember 2014. Pukul 11.53 WIB]

Widyantini, T. 2014. Penerapan Model Project Based Learning dalam (Model Pembelajaran Berbasis Proyek) dalam Materi Pola Bilangan Kelas VII. Artikel PPPPTK [Online]. Tersedia: http://p4tkmatematika.org/2014/04/penerapan-model-project-based-learning-model-pembelajaranberbasis-proyek-dalam-materi-pola-bilangan-kelas-vii/ [9 Oktober 2014. Pukul 2.09 WIB] 